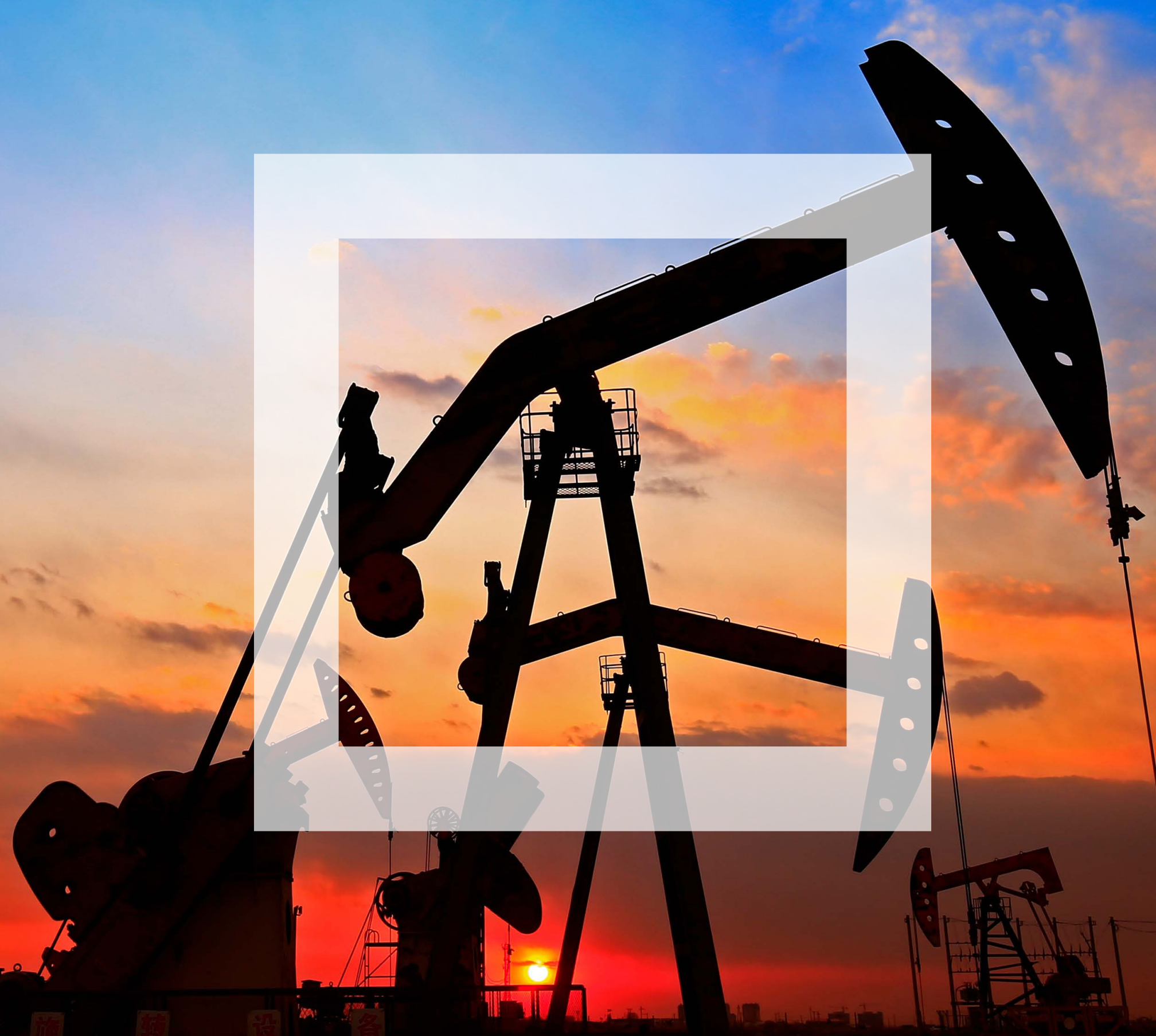

CLIMATE CHANGE RISK-RELATED DISCLOSURES IN EXTRACTIVE INDUSTRIES 


\section{About ACCA}

ACCA is the Association of Chartered Certified Accountants. We're a thriving global community of 227,000 members and 544,000 future members based in 176 countries that upholds the highest professional and ethical values.

We believe that accountancy is a cornerstone profession of society that supports both public and private sectors. That's why we're committed to the development of a strong global accountancy profession and the many benefits that this brings to society and individuals.

Since 1904 being a force for public good has been embedded in our purpose. And because we're a not-for-profit organisation, we build a sustainable global profession by re-investing our surplus to deliver member value and develop the profession for the next generation.

Through our world leading ACCA Qualification, we offer everyone everywhere the opportunity to experience a rewarding career in accountancy, finance and management. And using our respected research, we lead the profession by answering today's questions and preparing us for tomorrow.

Find out more about us at www.accaglobal.com

\section{About the Adam Smith Business School}

The University of Glasgow includes among its alumni, the father of economics, Adam Smith. The Adam Smith Business School is named in his honour. We aim to follow his legacy by developing enlightened, engaged and enterprising graduates, who are internationally recognised and make a positive impact on culture and society. Our business is about creating inspiring leaders, researchers and professionals whose research and relations with industry have real impact, influencing organisations as they develop and grow globally.

The Adam Smith Business School has the triple crown of accreditation as it is accredited by the Association to Advance Collegiate Schools of Business (AACSB International), the European Quality Improvement System (EQUIS) and the Association of MBAs (AMBA) for its MBA programme.

The School is home to research, of international and national excellence, that contributes to theoretical advancement and is relevant to practice. Two more recent examples reflecting this are the School's contribution to the Productivity Institute and the Adam Smith Observatory of Corporate Reporting Practices. The Productivity Institute will directly inform government policy to improve UK productivity. The Observatory is comprised of an international network of researchers in accounting with practice-based experience. It aims at providing accounting standard setters and regulators across the world with evidence-based inputs, such as this report, when the evidence is timely and directly relevant to the issues they tackle.

Find out more about us at www.gla.ac.uk/schools/business/aboutus/ 


\section{CLIMATE CHANGE RISK- RELATED DISCLOSURES IN EXTRACTIVE INDUSTRIES}

ACCA AND ADAM SMITH BUSINESS SCHOOL RESEARCH REPORT

Diogenis Baboukardos (University of Essex)

Dionysia Dionysiou (University of Stirling)

Richard Slack (Durham University)

loannis Tsalavoutas (University of Glasgow)

Fanis Tsoligkas (University of Bath)

For further information, please contact:

Richard Martin, Head of Corporate Reporting, ACCA richard.martin@accaglobal.com

Diogenis Baboukardos, Lecturer in Accounting,

Essex Business School, d.baboukardos@essex.ac.uk 


\section{Contents}

1. Introduction $\quad \mathbf{5}$

1.1 Background and objectives $\quad 5$

$\begin{array}{ll}1.2 \text { Method } & 6\end{array}$

1.3 Key findings $\quad 6$

$\begin{array}{ll}1.4 \text { Conclusions and policy recommendations } & 7\end{array}$

$\begin{array}{ll}1.5 \text { Report outline } & 7\end{array}$

2. Research approach $\quad 9$

2.1 Sample selection 9

2.2 Method of analysis 10

3. Findings and discussion 13

3.1 Overall findings 13

3.2 Front end 13

3.2.1 Reserves and resources reporting 13

3.2.2 Scenario analysis 14

$\begin{array}{ll}3.2 .3 \text { Business model } & 15\end{array}$

3.2.4 Performance indicators 16

3.2.5 TCFD recommendations 18

$\begin{array}{ll}3.3 \text { Back end } & 19\end{array}$

3.3.1 Accounting policies note 19

3.3.2 Impairment testing note 19

3.3.3 Non-current assets note $\quad 20$

3.3.4 Provisions and contingent liabilities note $\quad 21$

$\begin{array}{ll}3.3 .5 \text { Auditor's report } & 22\end{array}$

$\begin{array}{lr}\text { 4. Conclusions } & 24\end{array}$

$\begin{array}{ll}\text { About the authors } & 26\end{array}$

$\begin{array}{ll}\text { References } & 27\end{array}$

Appendix A: Sample companies $\quad 29$

Appendix B1: Instrument for annual report analysis: Front end $\quad 30$

Appendix B1: Instrument for annual report analysis: Back end

\section{Acknowledgements:}

The authors would like to thank ACCA and the Adam Smith Observatory of Corporate Reporting Practices for providing the funding for this project. We are grateful to Richard Martin (ACCA) for his valuable suggestions, support and advice during the project, and Alison Thomas for her useful comments. We also thank Evangelos Seretis for his excellent research assistance with the data collection. 


\section{Introduction}

\subsection{Background and objectives}

Climate change has been increasingly (and more urgently) recognised by governments and supranational organisations as one of the main risks that the planet and mankind are facing. A number of recent prominent initiatives, notably the 2015 Paris Agreement and the UN Sustainable Development Goals, aim at mitigating this risk by reducing emissions and, hence, restraining global warming. These developments have a direct impact on the business world and serious implications for specific industries: primarily the extractive industries, which face an urgent need to alter their operations substantially in order to survive in this new reality. ${ }^{1}$ Considering that companies in the extractive industries are responsible for almost half of global greenhouse gas (GHG) emissions (IRP 2019), climate change can no longer be seen as a side effect of their operations but as central issue for their business model and a core business risk.

Companies in the extractive industries possess significant reserves that are expected to yield future economic benefits and related assets can be recognised in their balance sheets, contributing to their stock market valuation. Nevertheless, there is a high risk that such assets may be rendered 'stranded' as a consequence of the recent developments in the fight against climate change (UNU WIDER 2017). Reduced demand for oil and reduced oil prices have led to underperforming wells, with companies abandoning offshore wells (Energypeople 2020) and exploring green alternatives for their future operations (Carbon Tracker Initiative 2020). Moreover, the COVID-19 pandemic appears to have accelerated the decarbonisation of economies. For instance, oil giants such as BP and Shell are now recognising significant asset impairment losses, citing the long-term effects of the pandemic on the demand for fossil fuels (Bousso 2020;
Meredith 2020). Nevertheless, the timing and pace of the decarbonisation is an open debate, creating tensions among top executives (Raval and Hook, 2020). In addition, mining companies face conflicting challenges: on the one hand, available mining reserves are increasingly deeper, and their ore grade is increasingly poorer, which heightens companies' demand for energy and water (Rüttinger and Vigya 2016). On the other hand, these companies face considerable regulatory and market pressures to reduce energy and water consumption (UNU WIDER, 2017).

As a result of the recent developments in the fight against climate change, the present value of the estimated future net cash flows generated from the use of these assets can be significantly reduced, which, in turn, would have substantial implications for companies' balance sheets and their market valuations. Hence, companies operating in the extractive industries face a potential shock to their market valuations due to climate change risks. ACCA (2016) notes that such a shock can be mitigated if these risks are known to the market and, hence, they can be incorporated into market participants' valuation processes. Thus, many voices call for relevant climate change risk disclosures to be made by companies (ACCA 2013, 2016; Anderson 2019; BDO 2020). In a similar vein, the IFRS Foundation notes that 'companies must consider climate related matters in applying IFRS Standards when the effect of those matters is material in the context of the financial statements taken as a whole' (IFRS Foundation 2020a:1).

The auditing profession has also shown particular interest in climate change risks and has urged practitioners to consider climate change risks in the audit of financial statements (IAASB 2020) and recommends that material climate-related risks not only be disclosed within the financial statements but also be discussed in the audit 
opinion (AASB and AUASB 2018). Finally, from a user perspective, capital providers have become increasingly concerned about climate change risks and the need for relevant disclosures. For instance, at the Rio 2012 Earth Summit, investors called for the integration of material sustainability issues within companies' annual reports (Assembly General, United Nations 2012). More recently, large investors call for mandatory inclusion of such information in companies' accounts (Mooney 2020) and the Bank of England expects climate change riskrelated financial disclosures to become mandatory (Jones 2020). In the absence of solid and informative disclosures about climate change risks, companies may be seen as being unprepared because they have not integrated a key business risk, potentially leading to a decline in investors' confidence (Climate-Related Market Risk Subcommittee 2020).

Against this backdrop and considering that 'the quality and quantity of these disclosures varies considerably' (ACCA 2016: 16), as well as the climate change urgency and related developments that we are witnessing in sustainability reporting, ${ }^{2}$ our study aims at shedding light upon current climate change-related reporting practices of companies in the extractive industries. The primary objectives of our study are to:

- explore the level and depth of climate-related disclosures provided by companies in the extractive industries in the narrative sections (ie front end) of their annual reports

- explore the level of integration of climate-related information into the accounting policies and relevant financial statements' notes in the financial reporting section (ie back end) of companies' annual reports, and

- identify good climate-related reporting practices in both the front and back ends of the annual reports.

\subsection{Method}

This study analyses the 2019 annual reports of 60 publicly listed companies in the extractive industries with the largest carbon emissions during the period 2016-18, measured by their average Scope 1 and Scope 2 carbon emissions ${ }^{3}$ over the period 2016-18. The carbon emissions were retrieved from Thomson Reuters' Eikon database. Companies that do not apply IFRS or equivalent local accounting standards, companies that do not have extractive activities (ie iron and steel producers) and companies with missing annual reports or with annual reports not in English are not considered in this study.

In order to address the objectives of our study, two separate research instruments were created. The first one was used to examine the front end of the annual reports and comprised 11 questions that explored reporting practices on 'Reserves and Resources'; 'Scenario Analysis'; 'Business Model'; 'Performance Indicators'; and 'Climaterelated Financial Disclosures'. The second instrument was used to examine the back end of the annual reports and comprised 14 questions that explored reporting practices on financial statements notes about Accounting Policies; Impairment Testing; Non-current Assets; Provisions and Contingent Liabilities and; Auditor's Report.

The annual reports of our 60 sample companies were reviewed manually. Our approach was twofold: we first calculated a score based on the number of disclosure items found in each report and we also went deeper and identified reporting practices for each disclosure item.

\subsection{Key findings}

The central message of this report is that companies do not sufficiently engage with disclosures about their climate change-related risks. Companies are found to provide, on average, overly generic disclosures and they refrain from discussing how climate change risks affect their operations. Furthermore, only a small number of companies acknowledge the central role of climate change on their current and future activities. ${ }^{4}$ Our findings

\footnotetext{
2 During the second half of 2020, a number of important developments took place, with the most prominent of them being: the IFRS Foundation's release of its Consultation Paper on Sustainability Reporting, which states that 'developing global sustainability-reporting standards for climate-related information is the most pressing concern' (IFRS Foundation 2020b: para 41); the announcement by the International Integrated Reporting Council (IIRC) and the Sustainability Accounting Standards Board (SASB) of their intention of merging into a new organisation called The Value Reporting Foundation, aiming at 'providing investors and corporates with a comprehensive corporate reporting framework across the full range of enterprise value drivers and standards to drive global sustainability performance' (IIRC and SASB 2020); the release of a common statement by the Carbon Disclosure Project, the Climate Disclosures Standards Board, the Global Reporting Initiative, the International Integrated Reporting Council and the Sustainability Accounting Standards Board of their intention of working together and arguing that: 'we have reached a pivotal moment that could usher in progress towards a more comprehensive solution for corporate reporting; one that is urgently needed to improve enterprises' contribution to sustainable development, to help address climate change and to enable more resilient, efficient financial markets' (Impact Management Project 2020).

3 According to Thomson Reuters' Eikon database, Scope 1 carbon emissions are companies' direct emissions from sources that are owned or controlled by the company. Scope 2 carbon emissions are companies' indirect emissions from consumption of purchased electricity, heat or steam which occur at the facility where electricity, steam or heat is generated. The following gases are considered: carbon dioxide (CO2), methane (CH4), nitrous oxide (N2O), hydrofluorocarbons (HFCS), perfluorinated compound (PFCS), sulfur hexafluoride (SF6), nitrogen trifluoride (NF3).

4 A similar lack of climate change risk-reporting was noted by Adams (2020) in relation to the airline industry.
} 
indicate that both the front and back ends of companies' annual reports lack clarity of and depth in climate changerelated disclosures. Also, it has become evident that the two ends of the annual report are relatively disconnected, as companies provide more information about their climate change-related risks in the front end than in the back end. Thus, it appears that financial reporting does not follow narratives in considering the effects of climate change on companies' operations.

Particularly, the key findings of our analysis can be summarised in the following points.

- Only $60 \%$ of the sample companies (36) provide a reserves/resources statement with relevant numerical information, whereas none of them present a detailed assessment of the climate change risks that are pertinent to their projects.

- Fewer than a quarter of our sample (14 companies) provide scenario analysis that considers/discusses climate change risks.

- Only $60 \%$ of our sample companies (36) identify addressing climate change risk as an integral part of their business model. Moreover, just 15 of them consider international initiatives for climate change (eg the Paris Agreement) in the discussion of their business model.

- Although most of our sample companies provide some form of climate change-related performance indicators (predominantly carbon emissions), only four companies provide performance indicators where financial and climate change-related information is integrated.

- Only $10 \%$ of our sample companies (6) disclose that they incorporate climate change risks in their estimations of future cash flows, as part of their impairment testing calculations.

- None of the sample companies identify climate change risk as an important factor in determining their assets' useful lives.

- Although all sample companies capitalise future climate change-related expenses as part of their property, plant and equipment costs or other non-current assets, only one-quarter of them (14 companies) use financial instruments to settle future obligations related to climate change.

- A very small number of our sample companies consider climate change risks in the estimation and recognition of provisions (fewer than 30\% (17 companies)) and contingent liabilities (10\% (6 companies)), respectively.

- In only $15 \%$ of our sample companies' audit reports (9) is climate change risk identified as a key audit matter.

\subsection{Conclusions and policy recommendations}

Our analysis reveals that, in the front end of their annual reports, companies in the extractive industries acknowledge, to some extent, the impact of climate change risks. Nevertheless, the information provided in the back end and the consideration of climate change-related risks in the judgements and estimates of companies' management rarely have depth and are far from complete. Very few of the sample companies discuss extensively and in a complete manner the impact of climate change risks on their future financial performance. Interestingly, the only financial reporting policy applied by all the companies is the capitalisation of provisions for rehabilitation and restoration expenses, bolstering their balance sheets even though the cash flow implications are rather uncertain.

Our findings can be of interest to accounting standard setters in considering the relevance of current financial reporting standards in communicating climate change-related risks (eg IFRS Foundation 2020a). It is indicated that much more needs to be done to improve such reporting in the financial statements. In particular, our results can be relevant to potential amendments of IAS 1 (ie key estimations and uncertainties) as well as IFRS 6 (Exploration for and Evaluation of Mineral Resources), IAS 36 (Impairment of Assets) and IAS 37 (Provisions, Contingent Liabilities and Contingent Assets) among others. Furthermore, our findings contribute to the current debate over the IFRS Practice Statement 1 Management Commentary suggesting that specific considerations about climate change risks disclosures are needed. Also, regulators and auditors need to consider more fully the quality of compliance and the reliability of relevant estimates. As reported above, the prominence of considering climate change risks of companies' operations is more evident in the front end of the annual report. This raises questions over the consistency, relevance and decision-usefulness of these companies' financial reporting.

Finally, our sample companies are some of the largest companies in the extractive industries. As it is evident in the accounting literature that the level of disclosure is positively associated with the size of a company, companies that are not examined in this report would be expected to provide, on average, lower levels of disclosure than our findings suggest. Hence, we believe that there is a more urgent need for improving climate change-related disclosures than even our empirical findings indicate.

\subsection{Report outline}

The next chapter describes the research design, sample selection process, sample identity and research instruments employed for the analysis of the annual reports. Chapter 3 presents and discusses our results. Conclusions are set out in Chapter 4. 


\section{ONLY $60 \%$ OF OUR SAMPLE COMPANIES (36) IDENTIFY ADDRESSING CLIMATE CHANGE RISK AS AN INTEGRAL PART OF THEIR BUSINESS MODEL.}

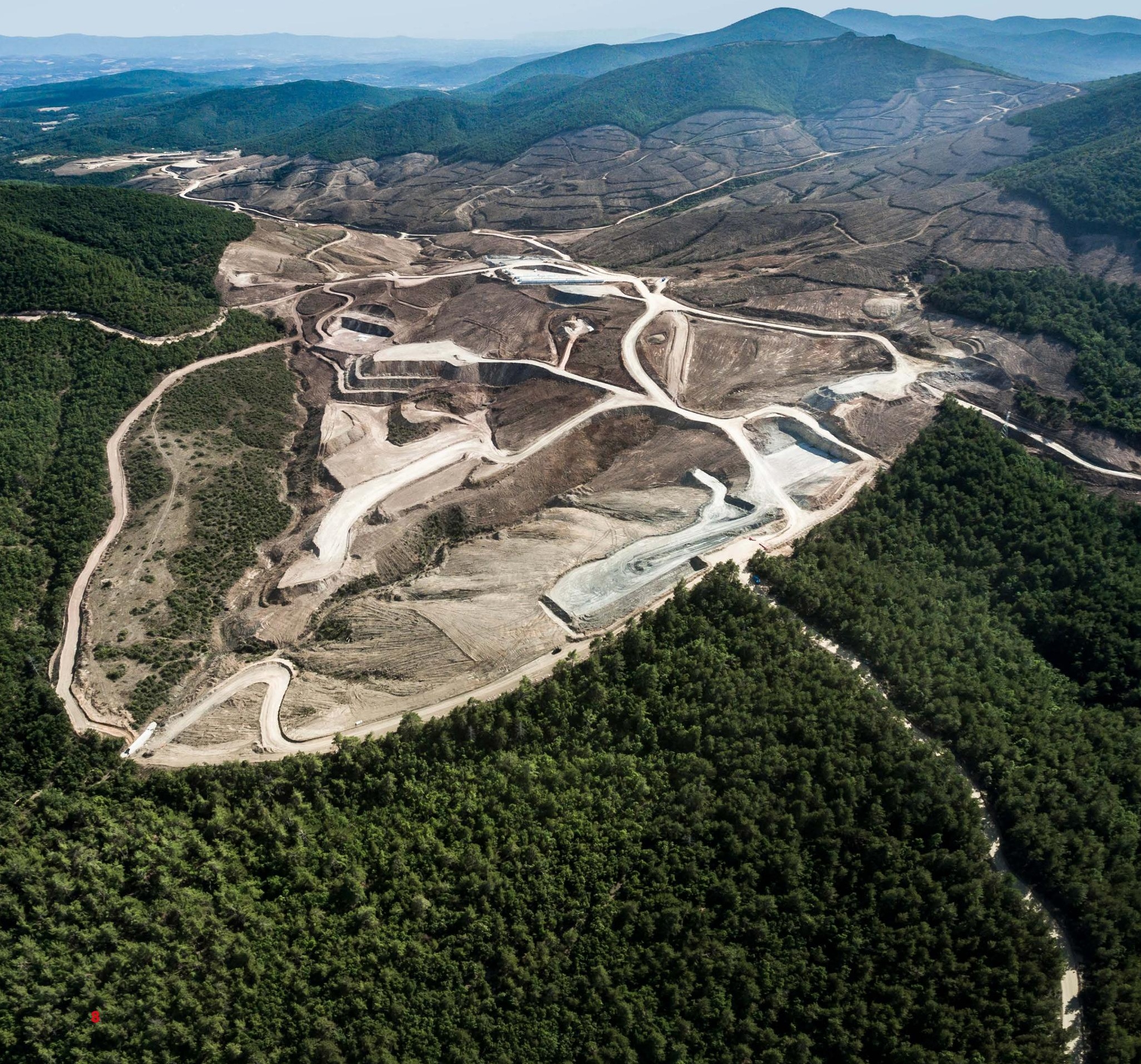




\section{Research approach}

\subsection{Sample selection}

The sample selection started by identifying all listed companies in Thomson Reuters Eikon database that belong to extractive industries. Specifically, we concentrated on the following industries of the Industry Classification Benchmark (ICB): alternative fuels; aluminum; coal; copper; diamonds and gemstones; general mining; gold mining; integrated oil and gas; iron and steel; offshore drill and services; oil: crude producers; platinum and precious metals. From the companies above, we excluded those that do not have extractive operations, companies that do not apply IFRS or equivalent local accounting standards, companies with missing or nonEnglish annual reports, and companies for which no complete $\mathrm{CO}_{2}$ Scope 1 and Scope 2 emissions data for the period 2016-18 is available in Thomson Reuters Eikon database. The latter criterion is used in order to ensure that our companies have exhibited consistently high $\mathrm{CO}_{2}$ emissions. Subsequently, we retained in our sample the 60 companies with the highest average total $\mathrm{CO}_{2}$ Scope 1 and Scope 2 emissions over the period 2016-18. Appendix A lists the companies included in the sample.

\section{FIGURE 2.1: Sample distribution by industry}

- Aluminum (1)

- Coal (1)

- Copper (3)

- General mining (7)

- Gold mining (4)

- Integrated oil and gas (24)

- Iron and steel (11)

- Oil: crude producers (6)

- Platinum and precious metals (3)

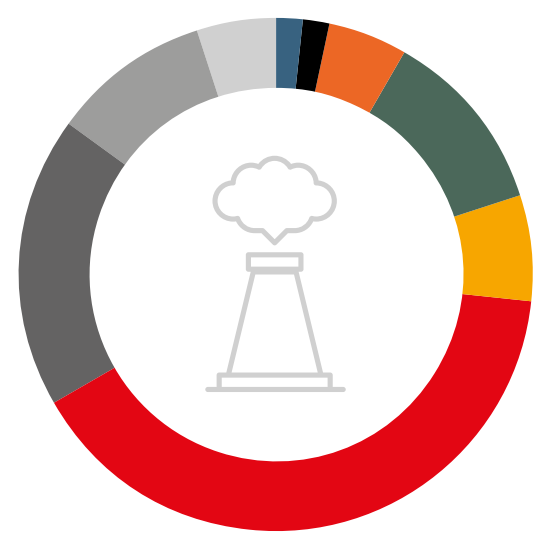

After these exclusions, of the 60 companies in our sample half belong to the oil and gas industry ( 24 integrated oil and gas; and 6 crude oil producers) and the other half are mining companies (iron and steel; general mining; gold; copper; platinum and precious metals; aluminum and coal). Figure 2.1 provides companies' distribution by sub-sectors. As regards their geographic distribution, almost half of the sample companies (29) are based in Europe, 11 in Asia, seven in North America, five in Oceania and four in both Africa and South America (Figure 2.2). Eight companies are from Russia and the UK respectively, seven from Canada, five from Australia and India, four from South Africa, three from Thailand and the remainder are from 15 other countries.

FIGURE 2.2: Sample distribution by geographic region

- Africa (4)

- Asia (11)

- Europe (29)

- North America (7)

- Oceania (5)

- South America (4)




FIGURE 2.3: Average total $\mathrm{CO}_{2}$ emissions (Scope 1 and Scope 2) by industry for the period 2016-18 and according to their contribution to the total $\mathrm{CO}_{2}$ emissions of our sample (in million metric tonnes)
- Aluminum (10.6)
- Coal (8.48)
- Copper (7.8)
- General mining (134.78)
- Gold mining (12.96)
- Integrated oil and gas (802.84)
- Iron and steel (479.46)
- Oil: crude producers (54.29)
- Platinum and precious metals (14.19)
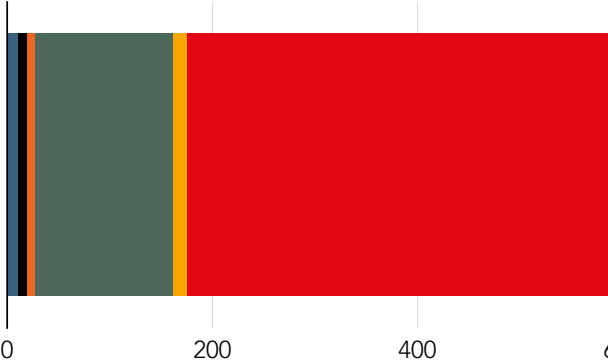

200

400

600
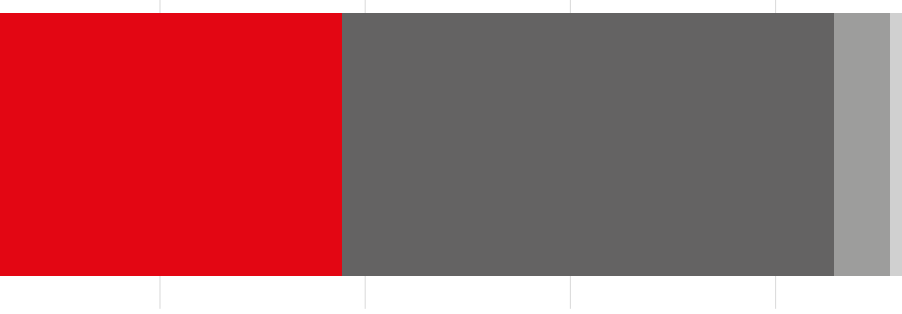

000

1200

1400

TABLE 2.1: Descriptive statistics of the sample

\begin{tabular}{|c|c|c|c|c|}
\hline & $\mathbf{N}$ & MEAN & MEDIAN & ST. DEV. \\
\hline Total assets (in $€ \mathrm{~m}$ ) & 60 & 57,499 & 23,989 & 77,939 \\
\hline ROA & 60 & 6.33 & 4.19 & 9.80 \\
\hline Market capitalisation (in $€ \mathrm{~m}$ ) & 60 & 31,336 & 13,921 & 38,872 \\
\hline
\end{tabular}

According to Thomson Reuters' Eikon database, the mean total $\mathrm{CO}_{2}$ Scope 1 and Scope 2 emissions of our sample companies for the period 2016-18 was 1,525m metric tonnes (Figure 2.3). Of these emissions, $57 \%$ are attributed to the oil industries (integrated oil and gas and crude oil producers). It is useful to point out that although the iron and steel industry represents $18 \%$ of the sample, it contributes more than $30 \%$ of the sample's total average carbon emissions.

Finally, Table 2.1 shows that the mean (median) total assets' value of the sample firms is $€ 57 \mathrm{bn}$ ( $€ 24 \mathrm{bn}$ ), the mean (median) market capitalisation is $€ 31 \mathrm{bn}$ ( $€ 14 \mathrm{bn}$ ) and the mean (median) ROA is 6.33\% (4.19\%).

\subsection{Method of analysis}

We first split each annual report in two parts. The first part (ie what we label as the 'Front end') consists of the narrative section of the annual report and includes, amongst others, the chairman's and CEO's statements, the strategic report (with a particular focus on the discussion of the business model), the 'Environmental, Social and Governance' (ESG) section as well as the 'Executive Remuneration' section. The second part includes the audited financial statements and the corresponding notes, as well as the auditor's report (ie what we label as the 'Back end'). For each part, we designed a corresponding tailored instrument to capture the extent of the integration of climate change implications in the companies' estimates and judgements about the sustainability of the firm as a whole and specific assets. These are outlined in Appendix $B$ and discussed here in detail.

As far as the Front end analysis is concerned, the instrument used is motivated by earlier studies in stranded assets, which indicate the areas where companies should enhance their climate change-related reporting (ACCA 2016, 2013). Hence, the instrument focuses on the following dimensions.

- Reserves and resources reporting: whether the company provides a reserves/resources statement with relevant numerical information. Information about the status, longevity and pricing of the reserves is expected to be found. Where the company is found to disclose such reporting, we examine whether this reporting includes an assessment of climate changerelated risks and/or liabilities that are pertinent to the company's projects.

- Scenario analysis: whether the company provides different scenarios for the vulnerability of its assets values at different price levels, taking into account climate change risks. Specifically, the focus is on whether the company has developed its own scenario 
analysis to test the resilience of its operations or has adopted a scenario analysis developed by other organisations (such as the International Energy Agency's Sustainable Development Scenario). Where the company had a scenario analysis, the depth of the related disclosures was examined. Specifically, we explored whether the company provides quantitative information about the climate change factors, assumptions and impacts. For instance, if the company adheres to the Paris Agreement, how does that affect its future operations?

- Business model: whether the company discusses its business model in its annual report. If it does so, then it was investigated to see whether it recognises and subsequently addresses climate change risk as an integral part of its business model. Finally, we also examined whether companies that recognise climate change as an important aspect of their business model adhere to international initiatives such as the Paris Agreement and the United Nations Sustainable Development Goals.

- Performance indicators: a first step was to consider whether the company discloses climate changerelated performance indicators, such as the amount of its carbon emissions and the amount of its capital expenditure that is used to address climate change risks. Second, we considered whether the company adopts an integrated reporting approach by providing performance indicators (Pls) that integrate financial and climate change-related information (for instance, carbon emissions in relation to revenues). Finally, the company's remuneration policy was reviewed to identify whether climate change performance indicators are connected to executives' remuneration.

- Task Force on Climate-related Financial Disclosures (TCFD) recommendations: whether the company follows the recommendations of the TCFD, which '... has developed a framework to help public companies and other organizations more effectively disclose climate-related risks and opportunities through their existing reporting processes' (TCFD website). Therefore, following the TCFD recommendations can be seen as a manifestation of the company's commitment to better climate changerelated disclosures.

For the analysis of the back end, the instrument was motivated by recent guidance on how financial reporting can satisfy investors' needs for information on climate changerelated risks (Anderson 2019; BDO 2020; IFRS Foundation 2020) and it focuses on the following dimensions:
- Accounting policies note: the accounting policies were reviewed for items that may be affected by climate change risks. Particularly, we examined whether climate change is recognised as an important factor in the company's judgements and sources of estimations uncertainty for its financial instruments, tangible and intangible assets, exploration and evaluation assets, impairment of assets, and provisions and contingent liabilities.

- Impairment testing note: the process of impairment testing requires estimation of uncertain future cash flows. As climate change can affect these cash flows, we examined whether climate change risk is recognised as affecting the cash flows and hence the recoverable amounts of tangible, intangible and evaluation and exploration assets.

- Non-current assets note: we explored the notes to the accounts to observe whether they recognise the effect of climate change risk on the company's estimations of its assets' useful economic lives and future cash flows. Further, we explored whether the company capitalises future expenses related to climate change (ie rehabilitation and restoration provisions), whether it uses financial instruments in order to secure funds to settle potential environmental obligations in the future and whether it recognises carbon allowances as intangible assets.

- Provisions and contingent liabilities note: companies in the extractive industries are subject to provisions and contingent liabilities mainly related to rehabilitation and restoration costs at the end of the useful life of their resources. Therefore, we examined whether the company discusses the motives, processes and disclosure policies of amounts relevant to environmental provisions. In addition, we examined whether the company discloses contingencies related to its operational impact on the environment.

- Auditor's report: the company's audit report was reviewed to identify whether climate change-related issues and/or risks are identified as key matters in the audit process. For instance, impairment testing of assets in the extractive industries may be heavily affected by climate change risks.

Finally, we recognise that companies may not explicitly mention climate change risks in their back end notes on their accounting policies, provisions and contingent liabilities although they may provide a discussion of environment-related issues within these specific sections of an annual report. Since these disclosures may indirectly refer to climate change, we considered an extensive discussion over environmental issues to be arguably relevant to climate change. 

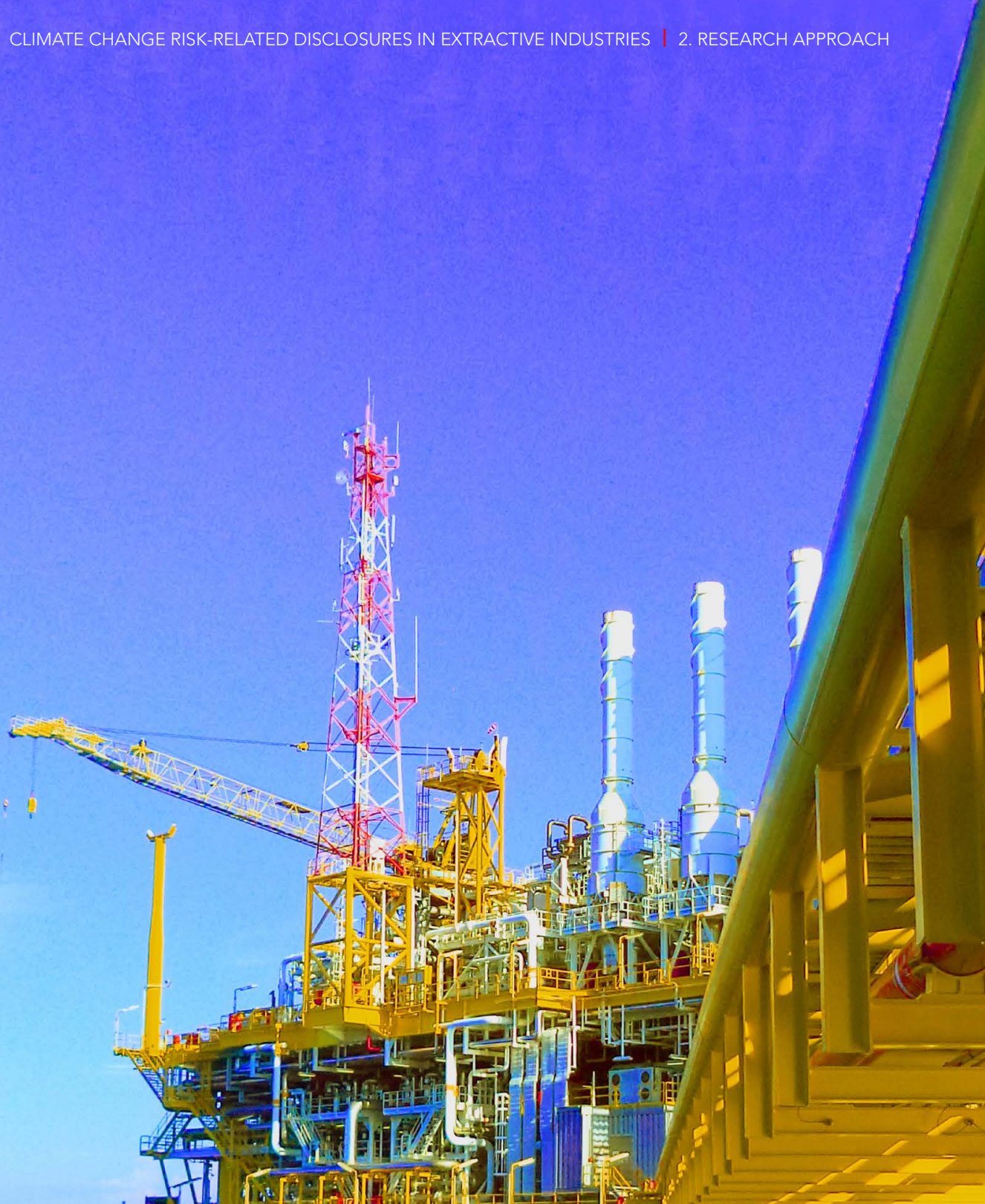


\section{Findings and discussion}

\subsection{Overall findings}

The analysis of our sample reveals that there is a substantial difference between the level of climate change disclosures in the front and back ends of the annual reports. Based on our research instruments, in the front end, the mean level of disclosures is about $40 \%$ whereas in the back end is 18\% (Figure 3.1). The difference between median levels of disclosure in the front and back ends is even larger ( $45 \%$ and $14 \%$ respectively).

From the above, it is evident that the two ends of the annual report are disconnected. Companies provide climate change-related information voluntarily in the front end, but this is not manifested in their financial accounts at the back end. Also, the results indicate that there is a

FIGURE 3.1: Average level of disclosures of the front and back ends

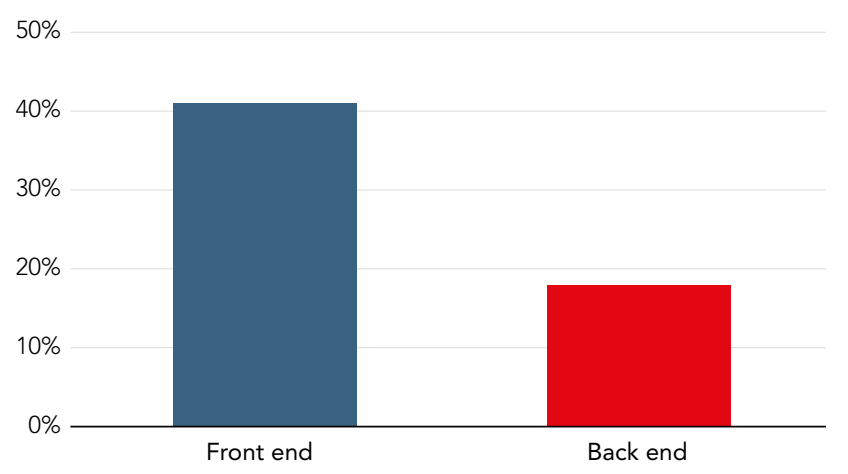

much larger variation in the provided disclosures in the front end than the back end (standard deviation of the front end disclosures is $25 \%$ whereas of the back end is $13 \%$ ). Finally, the level of disclosures in the two ends are positively correlated, which indicates that the back end disclosures, although lacking in quantity, follow the front disclosures.

\subsection{Front end}

\subsubsection{Reserves and resources reporting}

As indicated in Table 3.1, 36 companies (60\% of our sample) provide a reserves/resources statement and all include tabulated numerical information for their reserves/resources.

TABLE 3.1: Number of companies that provide a reserves/resources statement that includes relevant numerical information

\begin{tabular}{|l|c|c|}
\hline INDUSTRY & YES & NO \\
\hline Aluminum & 0 & 1 \\
\hline Coal & 0 & 1 \\
\hline Copper & 2 & 1 \\
\hline General mining & 6 & 1 \\
\hline Gold mining & 3 & 1 \\
\hline Integrated oil and gas & 14 & 10 \\
\hline Iron and steel & 3 & 8 \\
\hline Oil: crude producers & 5 & 1 \\
\hline Platinum and precious metals & 3 & 0 \\
\hline TOTAL & 36 & 24 \\
\hline
\end{tabular}


Further, none of our sample companies present an assessment of the climate change risks that are pertinent to their reserves and resources projects. Nonetheless, three South African companies mention climate changerelated risks in the description of their reserves, and four South African (again) companies have a separate report about reserves in which an assessment of climate change / environment- related risks is made. The following extract from Anglo American Plc reflects the type of disclosures provided by these seven firms.

'The Ore Reserve and Mineral Resource estimates presented in this report were prepared in accordance with the Anglo American plc Group Ore Reserves and Mineral Resources Reporting Policy. This policy requires that the Australasian Code for Reporting of Exploration Results, Mineral Resources and Ore Reserves 2012 edition (the JORC Code) be used as a minimum standard. Some Anglo American plc subsidiaries have a primary listing in South Africa where public reporting is carried out in accordance with the South African Code for Reporting of Exploration Results, Mineral Resources and Mineral Reserves (the SAMREC Code). The SAMREC Code is similar to the JORC Code and the Ore Reserve and Mineral Resource terminology appearing in this section follows the definitions in both the JORC (2012) and SAMREC (2016) Codes....The calculation of Mineral Resource and Ore Reserve estimates are (sic) based on long-term prices determined at the beginning of the second quarter of each year. Ore Reserves are dynamic and more likely to be affected by fluctuations in the prices of commodities, uncertainties in production costs, processing costs and other mining, infrastructure, legal, environmental, social and governmental factors which may impact the financial condition and prospects of the Group'. (Anglo American Plc 2019 annual report: 221)

\subsubsection{Scenario analysis}

Table 3.2 shows that 14 companies provide a scenario analysis and consider climate change risks.

The extract from Glencore Plc reflects the types of disclosure provided by these 14 firms.

'Our publication 2017 Climate change considerations for our business, evaluated each of our commodity departments against three key scenarios established by the International Energy Agency (IEA) and detailed in its World Outlook 2016 to determine their resilience and assess consequences for the portfolio of commodities we market. Our evaluation took into account price, supply, demand and industry structure, as well as the energy market projections developed by organisations such as the IEA and World Energy Council (WEC), leading climate science projections from the IPCC [the Intergovernmental Panel on Climate Change] and likely shifts in policy and
TABLE 3.2: Number of companies that provide a scenario analysis which considers climate change risks

\begin{tabular}{|l|c|c|}
\hline INDUSTRY & YES & NO \\
\hline Aluminum & 1 & 0 \\
\hline Coal & 0 & 1 \\
\hline Copper & 0 & 3 \\
\hline General mining & 4 & 3 \\
\hline Gold mining & 0 & 4 \\
\hline Integrated oil and gas & 7 & 17 \\
\hline Iron and steel & 0 & 11 \\
\hline Oil: crude producers & 1 & 5 \\
\hline Platinum and precious metals & 1 & 2 \\
\hline TOTAL & 14 & 46 \\
\hline
\end{tabular}

other conditions corresponding to scientific technology and economic changes. As the Paris Agreement requires each signatory country to outline and communicate their post-2020 climate actions, its revised national determined contributions (NDCs) by 2020 and we will provide an updated analysis of Glencore's portfolio resilience in 2021. In the interim, we are continuing to monitor policy developments and review our scenarios on an annual basis, taking into account any material changes to actual or proposed policies'. (Glencore 2019 annual report: 18)

In addition, Figure 3.2 shows that only 6 out of the 14 companies that provide scenario analysis with climate change-related information also provide specific quantitative information about relevant factors, assumptions and impacts.

FIGURE 3.2: Number of companies that provide, within their scenario analysis, quantitative information about the climate change factors, assumptions and impacts of their operations

- Yes (6)




The following extract from Eni SpA demonstrates a good example of relevant disclosure.

'Our portfolio of oil and gas properties features a large weight of natural gas, the least GHG-emitting fossil energy source, which represented approximately $49 \%$ of Eni's production in 2019 on an available-for-sale basis; as of December 31, 2019, gas reserves represented approximately $50 \%$ of Eni's total proved reserves of its subsidiary undertakings and joint ventures. The other pillar of our resilient portfolio of Oil \& Gas properties is the high incidence of conventional projects, developed through phases and with low $\mathrm{CO}_{2}$ intensity... We believe that those elements of our portfolio will mitigate the risk of stranded reserves going forward due to risks of lower hydrocarbons demand in response to stricter global environmental constraints and regulations and increasing public sensitivity to the issue of global warming... New projects' internal rates of return are stresstested against two sets of assumptions: i) Eni's management estimation of a cost per ton of carbon dioxide $\left(\mathrm{CO}_{2}\right)$, which is applied to the total GHG emissions of each capital project, while retaining the management scenario for hydrocarbons prices; and ii) the hydrocarbon prices and cost of $\mathrm{CO}_{2}$ emissions adopted in the International Energy Agency (IEA) Sustainable Development Scenario "IEA SDS"' (Eni SpA 2019 annual report: 94).

\subsubsection{Business model}

Surprisingly, our analysis reveals that almost $25 \%$ of our sample companies do not provide an explicit discussion of their business model (Table 3.3).

TABLE 3.3: Number of companies that provide an explicit discussion of their business model

\begin{tabular}{|l|c|c|}
\hline INDUSTRY & YES & NO \\
\hline Aluminum & 1 & 0 \\
\hline Coal & 1 & 0 \\
\hline Copper & 3 & 0 \\
\hline General mining & 6 & 1 \\
\hline Gold mining & 2 & 2 \\
\hline Integrated oil and gas & 19 & 5 \\
\hline Iron and steel & 9 & 2 \\
\hline Oil: crude producers & 2 & 4 \\
\hline Platinum and precious metals & 3 & 0 \\
\hline TOTAL & 46 & 14 \\
\hline
\end{tabular}

In addition, we find that most of the companies that disclose their business model (36 out of 46), identify addressing climate change risk as an integral part of it (Table 3.4).

TABLE 3.4: Number of companies that identify addressing climate change risk as an integral part of their business model.

\begin{tabular}{|l|c|c|}
\hline INDUSTRY & YES & NO \\
\hline Aluminum & 1 & 0 \\
\hline Coal & 1 & 0 \\
\hline Copper & 2 & 1 \\
\hline General mining & 5 & 1 \\
\hline Gold mining & 1 & 1 \\
\hline Integrated oil and gas & 15 & 4 \\
\hline Iron and steel & 7 & 2 \\
\hline Oil: crude producers & 1 & 1 \\
\hline Platinum and precious metals & 3 & 0 \\
\hline TOTAL & 36 & 10 \\
\hline
\end{tabular}

The following extract from Eni SpA is an indicative example of how companies identify how they approach climate change risk as an integral part of their business model.

'Eni's business model is focused on creating value for its stakeholders and shareholders through a strong presence along the whole value chain. Eni, as an integrated energy company, contributes, directly or indirectly, to achieve the goals of Sustainable Development (SDGs) of the UN 2030 Agenda, supporting a socially equal energy transition responding through concrete, quick and economically sustainable answers to the challenge of combating climate change and giving access to the energy resources in an efficient and sustainable way, overall. To manage this effectively, Eni integrates organically its industrial plan with the principles of environmental and social sustainability, enlarging its actions along three directives:

1. operational excellence,

2. carbon neutrality in the long term,

3. alliance for development'.

(Eni SpA 2019 annual report: 4) 
Despite the central role of international initiatives such as the Paris Agreement that aims at 'holding the increase in the global average temperature to well below $2^{\circ} \mathrm{C}$ above pre-industrial levels...' in order to '... reduce the risks and impacts of climate change' (UN 2015: Art. 2, para. 1a), only $25 \%$ of our sample companies (ie only $40 \%$ of those whose consideration of climate risk is an integral part of their business model (15 companies)) make a specific reference to international initiatives for climate change (eg the Paris Agreement) (Table 3.5).

TABLE 3.5: Number of companies that consider international initiatives for climate change (eg the Paris Agreement) in the discussion of their business model

\begin{tabular}{|l|c|c|}
\hline INDUSTRY & YES & NO \\
\hline Aluminum & 1 & 0 \\
\hline Coal & 0 & 1 \\
\hline Copper & 1 & 1 \\
\hline General mining & 1 & 4 \\
\hline Gold mining & 0 & 1 \\
\hline Integrated oil and gas & 7 & 8 \\
\hline Iron and steel & 3 & 4 \\
\hline Oil: crude producers & 0 & 1 \\
\hline Platinum and precious metals & 2 & 1 \\
\hline TOTAL & 15 \\
\hline
\end{tabular}

The following extract from Repsol illustrates a good example of how companies consider international initiatives for the climate change in their business models.

'In November, coinciding with the Climate Summit held in Madrid, the Board of Directors reviewed the company's role in the fight against climate change and made progress in its commitment to lead the energy transition in the industry, in line with the objectives of the Paris Summit and the United Nations' Sustainable Development Goals of reducing the increase in the planet's temperature to less than two degrees Celsius with respect to preindustrial levels... Repsol will therefore focus its strategy on achieving its goal of being a company with net zero emissions by 2050, thus becoming the first in its industry to pursue this ambitious goal'. (Repsol SA 2019 annual report (management report section): 13)

\subsubsection{Performance indicators}

The vast majority of our sample companies (51 out of 60) provide some form of climate change performance indicators (Table 3.6). The most representative indicator relates to the level of carbon emissions. This is usually compared to previous years' related carbon performance. Of those 51 companies, four provide indicators where financial and climate change-related information is integrated. For example, a company measures its carbon emissions as a percentage of its revenues (see extract from Evraz in Figure 3.3). Further, nine companies contrast their climate change-related performance indicators with relevant financial indicators (see extract from Galp Energia in Figure 3.4).

TABLE 3.6: Number of companies that provide climate change-related performance indicators.

\begin{tabular}{|l|c|c|}
\hline INDUSTRY & YES & NO \\
\hline Aluminum & 1 & 0 \\
\hline Coal & 0 & 1 \\
\hline Copper & 3 & 0 \\
\hline General mining & 7 & 0 \\
\hline Gold mining & 2 & 2 \\
\hline Integrated oil and gas & 21 & 3 \\
\hline Iron and steel & 10 & 1 \\
\hline Oil: crude producers & 4 & 2 \\
\hline Platinum and precious metals & 5 & 0 \\
\hline TOTAL & 51 \\
\hline
\end{tabular}

THE MOST REPRESENTATIVE INDICATOR RELATES TO THE LEVEL OF CARBON EMISSIONS. THIS IS USUALLY COMPARED TO PREVIOUS YEARS' RELATED CARBON PERFORMANCE. g 
FIGURE 3.3: Example of financial and climate change-related integrated information in performance indicators

\section{EVRAZ GHG emissions}

in 2019, million $\mathrm{tCO}_{2} \mathrm{e}$

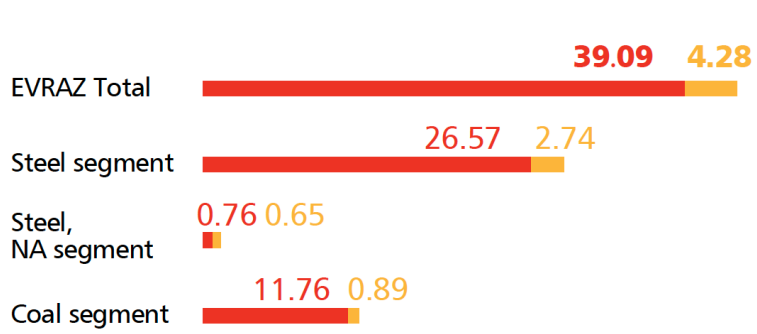

Direct emissions (Scope 1)

Indirect energy emissions (Scope 2)

\section{GHG emissions per revenue, $\mathrm{kg} \mathrm{CO}_{2} \mathrm{e} / \mathrm{US} \$$}



Coal segment

2019

2018

\section{3}

Source: Evraz 2019 annual report: 83

FIGURE 3.4: Example of reporting financial performance indicators alongside climate change-related performance indicators

Tackling the Climate Change Challenge



2022

\section{Reduction of $\mathrm{CO}_{2} \mathrm{e}$} emissions related with electricity purchased in Portugal by 2027

$100 \%$

\section{OUR}

PROGRESS



$$
77.18 \mathrm{gCO}_{2} \mathrm{e} / \mathrm{MJ}
$$

(\$) Planned investment

allocated to projects that promote energy transition

$40 \%$

Investment allocated

to projects that

promote energy

transition

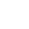


Table 3.7 indicates that only half the companies that provide climate change-related performance indicators link such metrics (or, more broadly, sustainability performance metrics) with their executives' remuneration.

TABLE 3.7: Number of companies that link executives' remuneration to climate change-related performance metrics.

\begin{tabular}{|l|c|c|}
\hline INDUSTRY & YES & NO \\
\hline Aluminum & 1 & 0 \\
\hline Coal & 1 & 0 \\
\hline Copper & 1 & 2 \\
\hline General mining & 5 & 2 \\
\hline Gold mining & 1 & 3 \\
\hline Integrated oil and gas & 12 & 12 \\
\hline Iron and steel & 2 & 9 \\
\hline Oil: crude producers & 2 & 4 \\
\hline Platinum and precious metals & 1 & 2 \\
\hline TOTAL & 26 \\
\hline
\end{tabular}

As is shown in the extract from Shell (Figure 3.5), 20\% of Shell's executives bonuses are connected to sustainability performance metrics.

\section{FIGURE 3.5: Basis of Shell annual bonuses}

2019 annual bonus outcome (audited) [A][B]

\begin{tabular}{|c|c|}
\hline Measures & $\begin{array}{r}\text { Weight } \\
\text { (\% of scorecard) }\end{array}$ \\
\hline Cash flow from operating activities (\$ billion) & $30 \%$ \\
\hline Operational excellence & $50 \%$ \\
\hline Production (kboe/d) & $12.5 \%$ \\
\hline LNG liquefaction volumes (mtpa) & $12.5 \%$ \\
\hline Refinery and chemical plant availability (\%) & $12.5 \%$ \\
\hline Project delivery on schedule (\%) & $6.25 \%$ \\
\hline Project delivery on budget (\%) & $6.25 \%$ \\
\hline Sustainable development & $20 \%$ \\
\hline Total recordable case frequency (injuries/million hours) & $5 \%$ \\
\hline Operational Tier 1 and 2 process safety events (number) & $5 \%$ \\
\hline $\begin{array}{l}\text { Upstream and Integrated Gas GHG intensity (tonnes of } \mathrm{CO}_{2} \\
\text { equivalent/tonne of hydrocarbon production available for sale) }\end{array}$ & $4 \%$ \\
\hline $\begin{array}{l}\text { Refining GHG intensity (tonnes } \mathrm{CO}_{2} \text { equivalent per Solomon's } \\
\text { Utilized Equivalent Distillation Capacity (UEDC'MM)) }\end{array}$ & $4 \%$ \\
\hline \multirow[t]{2}{*}{$\begin{array}{l}\text { Chemicals } \mathrm{GHG} \text { intensity (tonnes } \mathrm{CO}_{2} \text { equivalent/tonne of } \\
\text { petrochemicals production) }\end{array}$} & $2 \%$ \\
\hline & $100 \%$ \\
\hline
\end{tabular}

Source: Shell 2019 annual report: 142

\subsubsection{TCFD recommendations}

Although the Task Force on Climate-related Financial Disclosures (TCFD) is a relatively new endeavour, somewhat fewer than half our sample companies have already followed its recommendations (Figure 3.6) but some of them are even more actively involved in this. For instance, Tata Steel, as shown in the extract, not only follows the recommendations but is also a signatory of the TCFD.

'Climate change is recognised globally as one of the key risks in the 21st century. Tata Steel is a signatory to the Task Force on Climate Related Financial Disclosure (TCFD) and has undertaken a climate change risk assessment study in accordance with TCFD recommendations. Specific mitigation and contingency plans for each of the identified risks are being integrated with the Company's long-term strategy'. (Tata Steel 2019 annual report: 27)

FIGURE 3.6: Number of companies that follow the recommendations of the TCFD

- Yes (26)

- No (34)

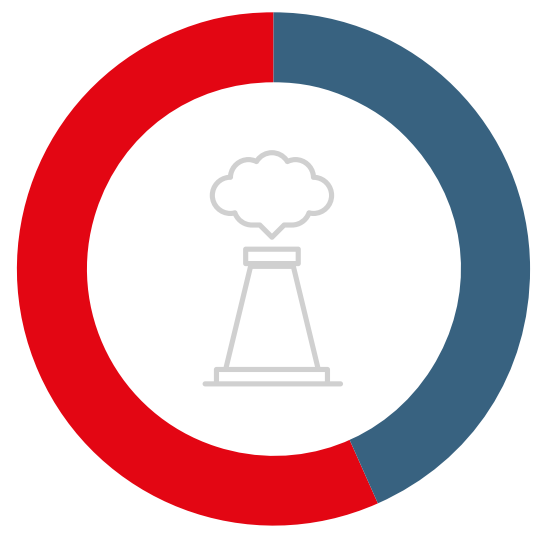

ALTHOUGH THE TASK FORCE ON CLIMATE-RELATED FINANCIAL DISCLOSURES (TCFD) IS A RELATIVELY NEW ENDEAVOUR, SOMEWHAT FEWER THAN HALF OUR SAMPLE COMPANIES HAVE ALREADY FOLLOWED ITS RECOMMENDATIONS, BUT SOME OF THEM ARE EVEN MORE ACTIVELY INVOLVED IN THIS. g 


\subsection{Back end}

\subsubsection{Accounting policies note}

No company recognises climate change as an important factor in its judgements and sources of estimations uncertainty in the accounting policies of its financial instruments. Only one recognises such a factor in the policies for its tangible and intangible assets, whereas 11 recognise it their impairment testing policy note. Finally, almost one-third of the companies (19) recognise climate change as an important factor in their policy notes for provisions and contingent liabilities (Figure 3.7). The extracts from BP and BHP illustrate two good examples of such disclosures in relation to these companies accounting policies for intangible assets and provisions, respectively.

\section{'Significant judgement: exploration and appraisal of} intangible assets

... BP is in the exploration and appraisal phase in certain Canadian oil sands assets that require further advancement of low-carbon extraction technology in order to achieve optimum development. Sufficient technological progress is expected to be achieved and therefore BP continues to carry the capitalized costs on its balance sheet' (BP 2019 annual report: 160).

'The recognition and measurement of closure and rehabilitation provisions requires the use of significant estimates and assumptions, including, but not limited to:

- the extent (due to legal or constructive obligations) of potential activities required for the removal of infrastructure and rehabilitation activities (including activities to mitigate the potential physical impact of climate change);...
... Estimates can also be impacted by the emergence of new restoration techniques, changes in regulatory requirements for rehabilitation, risks relating to climate change and the transition to a lower carbon economy, and experience at other operations'. (BHP 2019 annual report: 200)

\subsubsection{Impairment testing note}

Specifically in the notes discussing impairment testing of tangible and intangible assets, only $10 \%$ of our sample companies recognise climate change risk as an important factor in their assets' estimated future cash flows (Table 3.8). Further, although 48 companies recognise an impairment in relation to tangible or intangible assets, only three companies refer explicitly to climate change as an influential factor for the impairment recognised (Table 3.9).

TABLE 3.8: Number of companies that consider climate change risk as a factor in their assets' estimated future cash flows

\begin{tabular}{|l|c|c|}
\hline INDUSTRY & YES & NO \\
\hline Aluminum & 0 & 1 \\
\hline Coal & 0 & 1 \\
\hline Copper & 0 & 3 \\
\hline General mining & 1 & 6 \\
\hline Gold mining & 0 & 4 \\
\hline Integrated oil and gas & 5 & 19 \\
\hline Iron and steel & 0 & 11 \\
\hline Oil: crude producers & 0 & 6 \\
\hline Platinum and precious metals & 0 & 3 \\
\hline TOTAL & 6 & 54 \\
\hline
\end{tabular}

FIGURE 3.7: Number of companies that recognise enviornmental issues inclusive of climate change as an important factor in their judgements and sources of estimations uncertainty in the accounting policies note for the following items

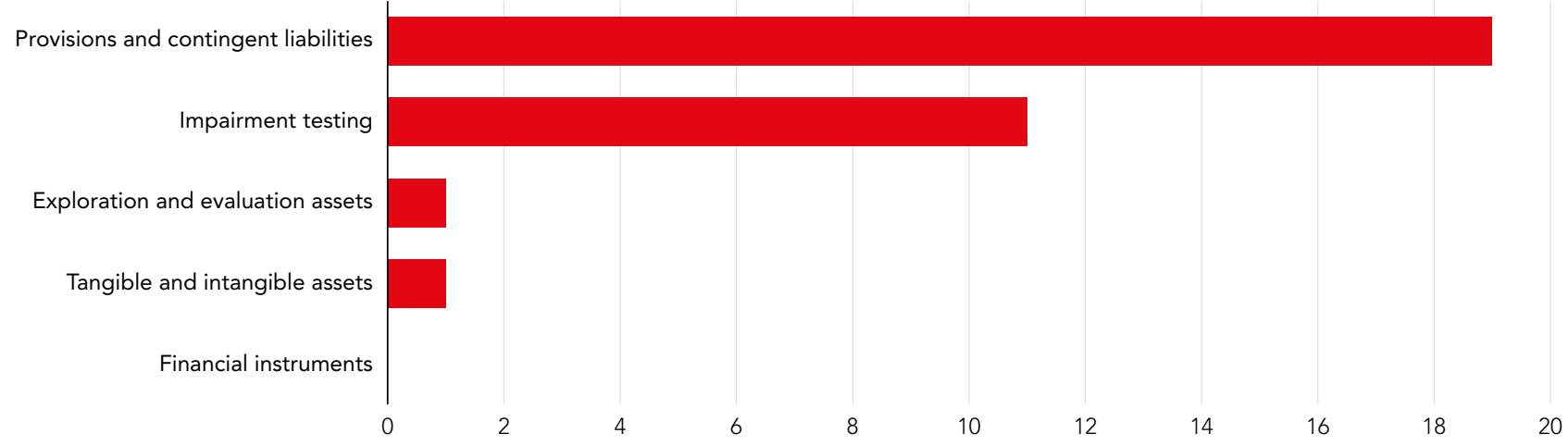


TABLE 3.9: Number of companies that recognise an impairment for tangible or intangible assets and refer explictly to climate change as an influential factor for the impairment recognised

\begin{tabular}{|l|c|c|}
\hline INDUSTRY & YES & NO \\
\hline Aluminum & 0 & 1 \\
\hline Coal & - & - \\
\hline Copper & 0 & 2 \\
\hline General mining & 0 & 6 \\
\hline Gold mining & 0 & 4 \\
\hline Integrated oil and gas & 3 & 18 \\
\hline Iron and steel & 0 & 8 \\
\hline Oil: crude producers & 0 & 4 \\
\hline Platinum and precious metals & 0 & 2 \\
\hline TOTAL & 3 & 45 \\
\hline
\end{tabular}

The extract from Repsol illustrates a good example of a company that considers climate change risk as an important factor in its assets' estimated future cash flows when performing impairment testing. The extract from Total is one of the three cases in our sample companies in which climate change is found to be an important factor in relation to impairment losses recognised in the year:

'The Group has assessed the recoverable amount of its cash-generating units as per the methodology described in Note 3 and the scenarios consistent with its new vision of the market, the expected environment and the new strategic approach. The main assumptions are described below:

...the general nature of the public policies and commitments aimed at the decarbonization of the economy and, therefore, at restricting the use of fossil fuels and the development of new alternative technologies that drive the energy transition and will mean a reduction in the demand for hydrocarbon products in the medium and long term should be noted. This will require companies to have a strategy in place to adapt to the energy transition that Repsol, following the analysis of its Board of Directors, has already begun by assuming decarbonization obligations that are in line with the climate change objectives of the Paris Agreement and the UN Sustainable Development Goals'. (Repsol 2019 annual report (financial statements): 53)

'In this context, given the need for the industry to make very substantial investments to cope with the natural decline of the fields, and meet the oil demand predicted by these scenarios over the next 20 years and given the slowdown in investment observed since 2015 in the oil and gas industry:

- the crude oil price level considered to determine the recoverable value of CGUs increases from $64 \$ 2018$ per barrel of Brent in 2019 to $70 \$ 2018$ in 2025, and would remain stable for the following five years. Afterwards, the price decreases to reach $50 \$ 2018$ in 2050, in line with the IEA's SDS scenario,

- as for gas, the price level considered to determine the recoverable value of CGUs stabilizes in the long term at approximately $6 \$ 2018 / M B T U$ for the NBP price (Europe) and 2.6\$2018/MBTU for the Henry Hub price (United States).

- the future operational costs were determined by taking into account the existing technologies, the fluctuation of prices for petroleum services in line with market developments and the internal cost reduction programs effectively implemented' (Total SE 2019 annual report: 306)

\subsubsection{Non-current assets note}

None of the sample companies identifies climate change risks as an important factor in determining the useful lives of its assets. At the same time, while all companies are found to capitalise future climate change-related expenses in their balance sheet, only 14 of them use financial instruments to settle future environmental obligations (Table 3.10).

TABLE 3.10: Number of companies using financial instruments in order to settle future environmental obligations

\begin{tabular}{|l|c|c|}
\hline INDUSTRY & YES & NO \\
\hline Aluminum & 0 & 1 \\
\hline Coal & 0 & 1 \\
\hline Copper & 1 & 2 \\
\hline General mining & 2 & 5 \\
\hline Gold mining & 1 & 3 \\
\hline Integrated oil and gas & 5 & 19 \\
\hline Iron and steel & 0 & 11 \\
\hline Oil: crude producers & 2 & 4 \\
\hline Platinum and precious metals & 3 & 0 \\
\hline TOTAL & 14 & 46 \\
\hline
\end{tabular}


The extract from Sibanye Stillwater is an example of a company that employs financial instruments for settling its future environmental obligations. Companies that employ such financial instruments secure funds in an attempt to render the settlement of these obligations more probable.

'The Group's rehabilitation obligation funds includes equity-linked investments that are fair valued at each reporting date. The fair value is calculated with reference to underlying equity instruments using industry valuation techniques and appropriate models...Annual contributions are made to dedicated environmental rehabilitation obligation funds to fund the estimated cost of rehabilitation during and at the end of the life of the relevant mine. The amounts contributed to these funds are included under non-current assets and are measured at fair value through profit or loss. Interest earned on monies paid to rehabilitation funds is accrued on a time proportion basis and is recorded as interest income... In addition, bank guarantees are provided for funding shortfalls of the environmental rehabilitation obligations' (Sibanye Stillwater 2019 annual report (financial report): 89).

Further, 11 companies capitalise carbon allowances as intangible assets; 10 of them are based in European countries and one in India (Table 3.11).

TABLE 3.11: Number of companies recognising carbon allowances as intangible assets

\begin{tabular}{|l|c|c|}
\hline INDUSTRY & YES & NO \\
\hline Aluminum & 1 & 0 \\
\hline Coal & 0 & 1 \\
\hline Copper & 0 & 3 \\
\hline General mining & 1 & 6 \\
\hline Gold mining & 0 & 4 \\
\hline Integrated oil and gas & 8 & 16 \\
\hline Iron and steel & 1 & 10 \\
\hline Oil: crude producers & 0 & 6 \\
\hline Platinum and precious metals & 0 & 3 \\
\hline TOTAL & 11 & 49 \\
\hline
\end{tabular}

TABLE 3.12: Number of companies that consider climate change-related risks in the estimation of their provisions

\begin{tabular}{|l|c|c|}
\hline INDUSTRY & YES & NO \\
\hline Aluminum & 1 & 0 \\
\hline Coal & 0 & 1 \\
\hline Copper & 0 & 3 \\
\hline General mining & 4 & 3 \\
\hline Gold mining & 0 & 4 \\
\hline Integrated oil and gas & 7 & 17 \\
\hline Iron and steel & 3 & 8 \\
\hline Oil: crude producers & 0 & 6 \\
\hline Platinum and precious metals & 2 & 1 \\
\hline TOTAL & 17 & 43 \\
\hline
\end{tabular}

The Polish company Polskie Gornictwo Naftowe i Gazownictwo is one of our sample companies that recognise carbon allowances as an intangible asset. The extract illustrates how this company treats carbon allowances.

\section{' $\mathrm{CO}_{2}$ emission allowances}

Pursuant to the Act on Trading in Greenhouse Gas Emission Allowances, the Group holds $\mathrm{CO}_{2}$ emission allowances allocated for individual installations.

The Group classifies emission allowances as:

1. Acquired for redemption - recognised as intangible assets and measured in accordance with the policies discussed below,

2. Acquired for resale - recognised as inventory (Note 6.2.1) and measured initially at cost; at the end of each reporting period they are measured at the lower of cost or net realisable value,

3. Received free of charge under the National Allocation Plan - recognised as off-balance-sheet items at nominal value (equal to zero)'. (Polskie Gornictwo Naftowe i Gazownictwo SA 2019 annual report: 46)

\subsubsection{Provisions and contingent liabilities note} In relation to provisions and contingent liabilities, 17 companies recognise provisions explicitly related to climate change risks (Table 3.12) whereas only six recognise climate change risk as an important determinant of their contingent liabilities (Table 3.13). 
TABLE 3.13: Number of companies that identify climate change risk as an important factor in their contingent liabilities

\begin{tabular}{|l|c|c|}
\hline INDUSTRY & YES & NO \\
\hline Aluminum & 0 & 1 \\
\hline Coal & 0 & 1 \\
\hline Copper & 0 & 3 \\
\hline General mining & 0 & 7 \\
\hline Gold mining & 1 & 3 \\
\hline Integrated oil and gas & 4 & 20 \\
\hline Iron and steel & 1 & 10 \\
\hline Oil: crude producers & 0 & 6 \\
\hline Platinum and precious metals & 0 & 3 \\
\hline TOTAL & 6 & 54 \\
\hline
\end{tabular}

The extract from Shell is a characteristic example of a company's contingent liabilities related to climate change risk.

\section{'Climate change litigation}

In the USA, 12 lawsuits have been filed by several municipalities and one state against oil and gas companies, including Royal Dutch Shell plc. The plaintiffs seek damages for claimed harm to their public and private infrastructure from rising sea levels allegedly due to climate change caused by the defendants' fossil fuel products. A similar suit has been filed by a crab fishing industry group claiming harm to their fisheries as a result of alleged ocean-related impacts of climate change. In the Netherlands a case has been filed against Shell by a group of environmental nongovernmental organisations ("eNGOs") and individual claimants seeking a court order that Shell reduce by (net) 100\% by 2050 the emissions associated with its business activities and products. Management believes the outcome of these matters should be resolved in a manner favourable to Shell, however, there remains a high degree of uncertainty regarding the ultimate outcome of these lawsuits, as well as their potential effect on future operations, earnings, cash flows and Shell's financial condition'. (Shell 2019 annual report: 236)

\subsubsection{Auditor's report}

Auditors do not recognise climate change risks in companies' current and future operations. Climate change-related risks that give rise to key audit matters was only recognised on nine occasions (Table 3.14). Figure 3.8 presents one of the few companies whose auditors identify climate change risk as key audit matter.

TABLE 3.14: Number of companies whose auditors acknowledge that climate change gives rise to key audit matters

\begin{tabular}{|l|c|c|}
\hline INDUSTRY & YES & NO \\
\hline Aluminum & 0 & 1 \\
\hline Coal & 0 & 1 \\
\hline Copper & 0 & 3 \\
\hline General mining & 3 & 4 \\
\hline Gold mining & 0 & 4 \\
\hline Integrated oil and gas & 5 & 19 \\
\hline Iron and steel & 1 & 10 \\
\hline Oil: crude producers & 0 & 6 \\
\hline Platinum and precious metals & 0 & 3 \\
\hline TOTAL & 9 \\
\hline
\end{tabular}

\section{FIGURE 3.8: Key audit matters as identified in BP's audit report}

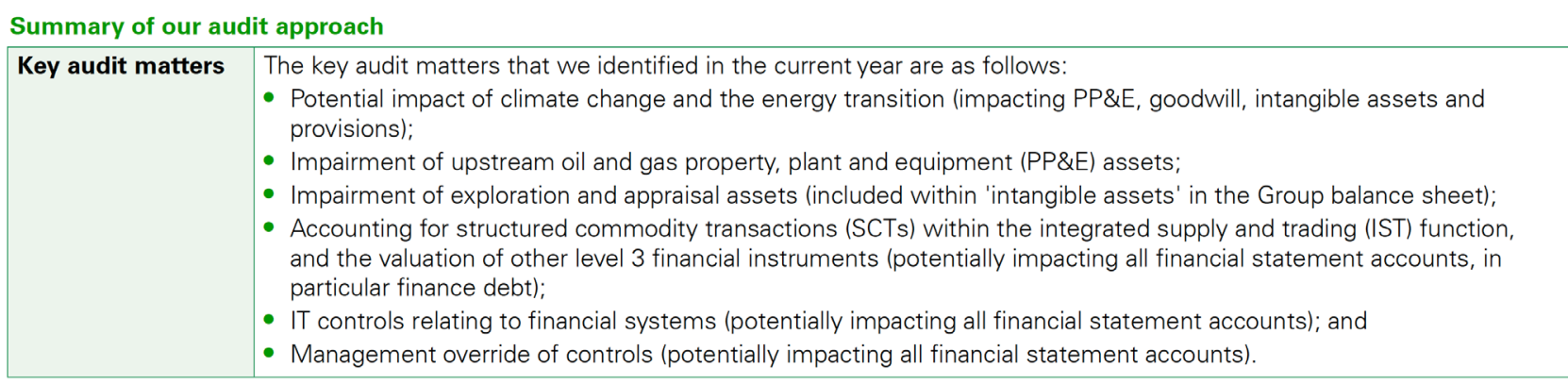



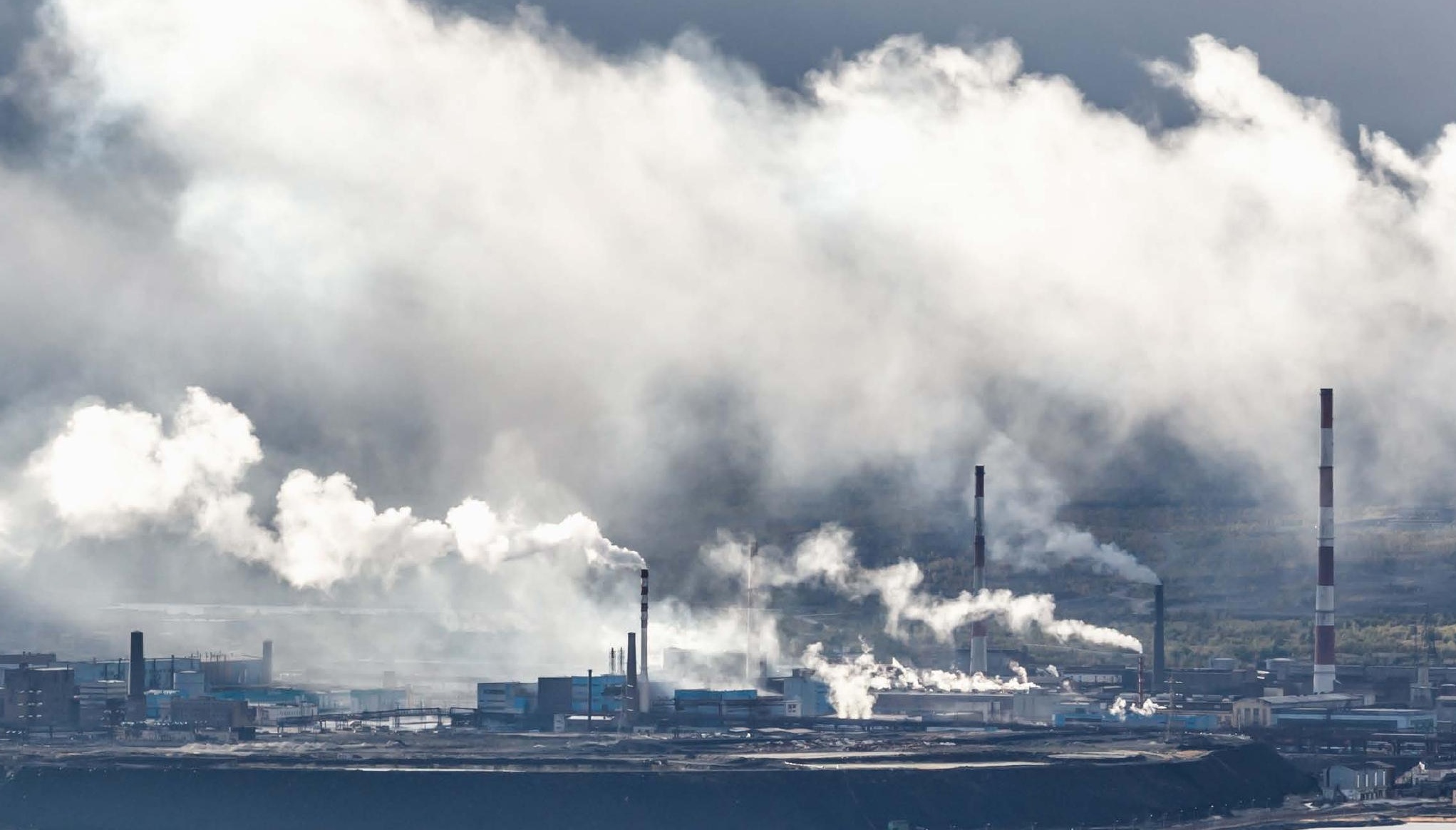

3.


4. H. 1.



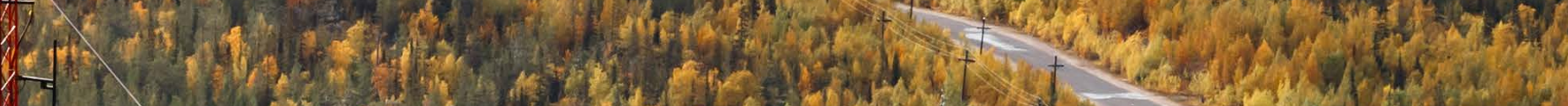

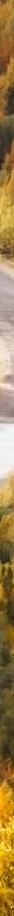




\section{Conclusions}

\section{As mankind intensifies efforts to mitigate the catastrophic consequences of climate change through international initiatives such as the Paris Agreement and the UN Sustainable Development Goals, companies in the extractive industries, being responsible for half of global carbon emissions (IRP 2019), are facing an ever-increasing challenge: to address the urgent issue of climate change and, at the same time, to remain competitive.}

These companies have large reserves that may be rendered 'stranded' if governments decide to ban oil production, as Denmark announced recently (Ambrose 2020) or owing to reduced demand (Energypeople, 2020) and commodity prices. The current pandemic has further raised awareness of the importance of preserving the natural environment and has accelerated countries' efforts to adopt environment-friendly policies (Bousso 2020; Meredith 2020) and green energy. In the light of these developments, it is not surprising that the accountancy/ auditing profession as well as the investor community and other capital providers, are urging companies to provide more disclosures, in both the front and the back ends of their annual reports, about the climate change-related risks they face, (AASB and AUASB 2018; ACCA 2013, 2016; Anderson 2019; Assembly General, United Nations 2012; BDO 2020; Climate-Related Market Risk Subcommittee 2020; IAASB 2020; Jones 2020).

Our study contributes to these developments by analysing climate change-related disclosures found in the 2019 annual reports of 60 publicly listed companies in the extractive industries that apply IFRS or local equivalent standards and have the largest carbon emissions during the period 2016-18. Our results indicate an overall low level of the quantity and, to some extent, quality of such disclosures. The vast majority of our sample companies refrain from providing adequate climate change-related disclosures. There is rarely an in-depth discussion about the climate change risks that they are facing or the impact of climate change risks on their operations.
Specifically, our sample companies provide much more information in the front, unaudited, part of their annual reports than in the back end, where they are parsimonious with it. In the latter, most of the companies do not discuss the topic of climate change at all and those that do cover it in a rather superficial manner without providing any numerical information. Even more alarming, the disclosures provided in the front end of the annual reports are not necessarily connected to the limited disclosures and estimates in the back end. This raises potential concerns about the usefulness of the front end disclosures and the reliability and decision usefulness of items recognised in the companies' financial statements (back end), and the consequent overall quality of the annual reports.

In the front end, just over half the companies provide a reserves/resources statement with relevant numerical information but without any reference to the climate change risks that are pertinent to their projects. More importantly, although climate change plays or will play an undoubtedly central role in these companies' operations, only $60 \%$ of them identify the need to address climate change risk as an integral part of their business model and only $25 \%$ of them consider international initiatives for climate change in the discussion of their business model. Finally, while our sample shows that some companies engage in reporting climate change through performance indicators, very few of them connect these indicators either directly or indirectly to financial performance indicators. Moreover, in most cases such climate change performance indicators were not linked to executives' remuneration. 
In the back end, very few companies engage in reporting estimates or judgements based on their climate change risk. No company recognises climate change risks as an important factor in its assets' useful lives and only 10\% of the sample companies disclose that they take into consideration climate change risks when estimating future cash flows for the impairment testing of their assets. In general, provisions and contingent liabilities also fail to reflect climate change risks. While all 60 companies capitalise future climate change-related costs as part of the cost of various non-current assets, only one-quarter of them create relevant savings using financial instruments in order to ensure that they will have the necessary capital to settle these obligations in the future. From an audit perspective, only $15 \%$ of our sample auditors' reports identify climate change risk as a key audit matter.

On a more positive note, we have witnessed some encouraging developments during 2020, which could influence companies' future reporting and integration of climate change into their reports. For instance, the sustainable financial agreements Eni SpA signed in 2020 with leading banks link loans and credit lines of more than $€ 4 b n$ to sustainability performance objectives, as outlined in UN SDG 7 'Affordable and clean energy', and to SDG 13 'Climate action' (Eni.com 2020) as well as to other reporting frameworks. This could be a fruitful avenue for future research.

As a closing note, we acknowledge that our research is bounded by two limitations. First, our findings about accounting policies, provisions and contingent liabilities include findings from companies that discuss their environmental impact, without necessarily making explicit reference to climate change. Had a stricter approach been taken, our results about the back end would reveal even lower level of disclosures. Second, because one of the aims is to examine the integration of climate change risks into companies' financial statements, our analysis focuses on the companies' annual reports only. We do not consider other reporting media that may include detailed relevant information.

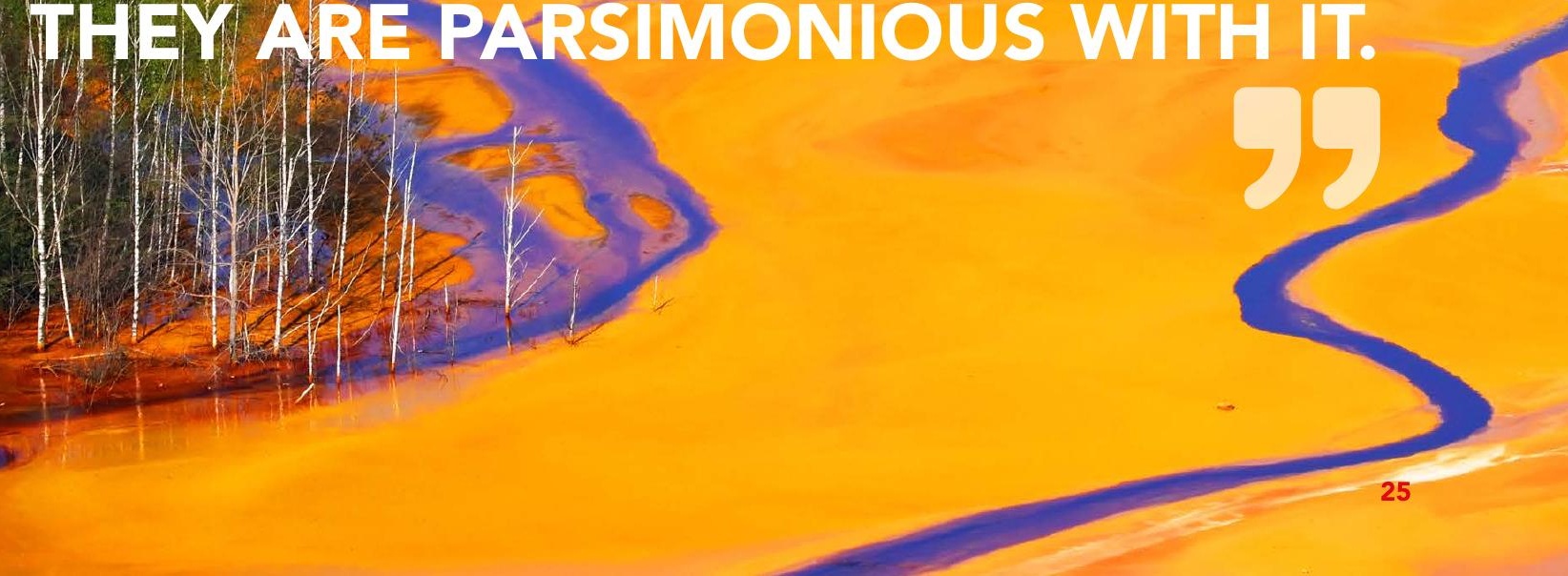




\section{About the authors}

\begin{abstract}
Dr Diogenis Baboukardos, University of Essex
Diogenis is a lecturer (assistant professor) in accounting at the University of Essex. Before that, he held teaching and research appointments in Greece and Sweden. His main research interests lie in the fields of financial accounting and corporate reporting. He is particularly interested in issues related to financial reporting; sustainability reporting; integrated reporting; and corporate governance. Diogenis also has a rich professional record with extensive experience in accounting and taxation consultancy positions in Greece. His main professional expertise is related to financial management, financial reporting and tax compliance.
\end{abstract}

\section{Dr Dionysia Dionysiou, University of Stirling Dionysia is a senior lecturer in accounting and finance at the University of Stirling. Before that, Dionysia was a researcher within the INTACCT network, where she worked on the implications of the mandatory implementation of IFRS in European countries. Dionysia's main areas of research interests are in corporate finance and corporate distress, as well as financial reporting and market-based accounting. She has published in internationally acclaimed journals in these areas and, for her practice-relevant research, she has received research grants from the Institute of Chartered Accountants of Scotland (ICAS) and ACCA.}

\section{Dr Richard Slack, Durham University}

Richard is a professor in accounting at Durham University Business School. Richard joined Durham University in 2012, having previously been professor in accounting at Newcastle Business School, Northumbria University. Before his academic career, Richard, a graduate of St Andrews University, worked at Price Waterhouse and is a qualified chartered accountant. Richard's research encompasses areas of accounting information, and its use by, and usefulness to, capital market users. Further, Richard is interested in the way information is presented by companies and whether narrative disclosure is decisionuseful to stakeholder groups.

\section{Dr Ioannis Tsalavoutas, University of Glasgow loannis is a professor of accounting at the University of Glasgow. His main area of expertise is financial accounting and reporting: in particular, investigating companies' reporting practices under IFRS across different jurisdictions, along with any economic consequences that may arise from divergence in practice. loannis' work experience includes positions as an accounting assistant (in Greece) and as a financial accounting and reporting analyst at Company Reporting Ltd in Edinburgh. Before joining the University of Glasgow in January 2015, loannis was a lecturer in accounting at the University of Stirling.}

\section{Dr Fanis Tsoligkas, University of Bath}

Fanis is a lecturer in accounting at the University of Bath. His main research interests lie in the fields of financial reporting discretion and the adoption of IFRS. They also include the capital market effects of accounting information and the effect of the trading behaviour of corporate executives and directors. Before joining academia, Fanis practised accountancy in Greece. 


\section{References}

AASB and AUASB (Australian Accounting Standards Board and Auditing \& Assurance Standards Board) (2018), Climate-related and other Emerging Risks Disclosures: Assessing Financial Statement Materiality Using AASB Practice Statement 2, <https:// www.aasb.gov.au/admin/file/content102/c3/AASB_AUASB_Joint_ Bulletin_13122018_final.pdf>, accessed 2 December 2020.

ACCA (2013), Carbon Avoidance? Accounting for the Emissions Hidden in Reserves, <http://www.accaglobal.com/content/dam/ acca/global/PDF-technical/sustainability-reporting/tech-tp-ca. pdf>, accessed 3 December 2020.

ACCA (2016), Filling the Information Black Hole: How are Fossil Fuel Companies Reporting on the Stranded Asset Risk, <https:// www.accaglobal.com/content/dam/ACCA_Global/Technical/oilgas/ea-stranded-assets.pdf>, accessed 3 December 2020.

Adams, C. (2020), 'Airlines, COVIID-19, Climate Change and Risk Reporting' [website article], 2 April <https://drcaroladams.net/ airlines-covid-19-climate-change-and-risk-reporting>, accessed 15 December 2020.

Ambrose J. (2020), 'Denmark to End New Oil and Gas Exploration in North Sea' [online article] <https://www.theguardian.com/ business/2020/dec/04/denmark-to-end-new-oil-and-gasexploration-in-north-sea>, accessed 7 December 2020.

Anderson, N. (2019), 'IFRS Standards and Climate-related Disclosures', republished in Effects of Climate-related Matters on Financial Statements: International Financial Reporting Bulletin 20/14, <https://cdn.ifrs.org/-/media/feature/news/2019/ november/in-brief-climate-change-nick-anderson.pdf?la=en>, accessed 3 December 2020.

Assembly General, United Nations (2012), 'Resolution Adopted by the General Assembly on 27 July 2012' <https://www.un.org/ga/ search/view_doc.asp?symbol=A/RES/66/288\&Lang=E $>$ accessed 7 December 2020.

BDO (2020), Effects of Climate-related Matters on Financial Statements, International Financial reporting Bulletin 2020/14, $<$ https://www.bdo.global/getmedia/1611afd9-46ff-41da-a80b560255754a0d/IFRB-2020-14-IFRS-Foundation-publishes-Effectsof-climate-related-matters-on-financial-statements.pdf.aspx>, accessed 7 December 2020.

Bousso, R. (2020), 'BP Wipes up to $\$ 17.5$ billion from Assets with Bleaker Oil Outlook', [website article] Reuters, 15 June $<$ https:// www.reuters.com/article/us-bp-writeoffs-idUSKBN23M0QA>, accessed 4 December 2020.

Carbon Tracker Initiative (2020), The Future's not in Plastics [website article] <https://carbontracker.org/reports/the-futuresnot-in-plastics/>, accessed 3 December 2020.
Climate-Related Market Risk Subcommittee (2020), Managing Climate Risk in the U.S. Financial System. Washington, D.C.: U.S. Commodity Futures Trading Commission. <https://www. cftc.gov/sites/default/files/2020-09/9-9-20\%20Report\%20of\%20 the\%20Subcommittee\%20on\%20Climate-Related\%20Market\%20 Risk\%20-\%20Managing\%20Climate\%20Risk\%20in\%20the\%20 U.S.\%20Financial\%20System\%20for\%20posting.pdf>, accessed 3 December 2020

Energypeople (2020), 'Underperforming Offshore Wells Rack Up Over $\$ 100$ billion in Abandonment Liabilities Worldwide' (website article], <https://energypeople.com/news/story/underperformingoffshore-wells-rack-up-over--100-billion-in-abandonmentliabilities-worldwide>, accessed 4 December 2020.

Eni.com (2020), 'Eni Links its Financial Instruments to the United Nations Sustainable Development Goals' [website article], 10 December <https://www.eni.com/en-IT/media/pressrelease/2020/12/eni-links-its-financial-instruments-united-nationssustainable-development-goals.html> accessed 15 December 2020.

IAASB (International Auditing and Assurance Standards Board) (2020), 'The Consideration of Climate-related Risks in an Audit of Financial Statement', Staff Audit Practice Alert October, <https:// www.ifac.org/system/files/publications/files/IAASB-Climate-AuditPractice-Alert.pdf $>$ Accessed 7 December 2020.

IFRS Foundation (2020a), Effects of Climate-related Matters on Financial Statements, <https://www.ifrs.org/-/media/feature/ supporting-implementation/documents/effects-of-climate-relatedmatters-on-financial-statements>, accessed 3 December 2020.

IFRS Foundation (2020b), Consultation Paper on Sustainability Reporting, <https://cdn.ifrs.org/-/media/project/sustainabilityreporting/consultation-paper-on-sustainability-reporting.pdf>, accessed 7 December 2020

Impact Management Project (2020), Statement of Intent to Work Together towards Comprehensive Corporate Reporting: Summary of Alignment Discussions among Leading Sustainability and Integrated Reporting Organisations CDP, CDSB, GRI, IIRC and SASB, September, <https://29kjwb3armds2g3gi4lq2sx1wpengine.netdna-ssl.com/wp-content/uploads/Statement-ofIntent-to-Work-Together-Towards-Comprehensive-CorporateReporting.pdf $>$, accessed 7 December 2020.

IRC and SASB (International Integrated Reporting Council and Sustainability Accounting Standards Board) (2020), 'IIRC and SASB Announce Intent to Merge in Major Step towards Simplifying the Corporate Reporting System' [website article], 25 November, $<$ https://www.prnewswire.com/news-releases/iirc-and-sasbannounce-intent-to-merge-in-major-step-towards-simplifying-thecorporate-reporting-system-301180179.html?tc=eml_cleartime $>$, accessed 7 December 2020. 
IRP (International Resource Panel) (2019), Global Resources Outlook 2019: Natural Resources for the Future We Want. A Report of the International Resource Panel, United Nations Environment Programme. Nairobi, Kenya.

Jones, H. (2020), 'Bank of England says company disclosures on climate risks will be mandatory', [website article], Reuters, 16 October <https://uk-mobile-reuters-com.cdn.ampproject.org/c/s/ uk.mobile.reuters.com/article/amp/idUKKBN2711DV>, accessed 4 December 2020

Meredith, S. (2020), 'Oil Major Shell to Write Down up to $\$ 22$ billion of Assets in Second Quarter, [website article], Reuters, 30 June, $<$ https://www.cnbc.com/2020/06/30/shell-to-write-down-assetsworth-up-to-22-billion-in-q2.html>, accessed 4 December 2020.

Mooney, A. (2020), 'Calpers, Schroders Call for Mandatory Inclusion of Climate Risks in Accounts' [online article], Financial Times, 15 August, < https://www.ft.com/content/09444686-e4da4360-98ba-51fc670c3826>, accessed 4 December 2020.
Raval, A. and Hook, L. (2020), 'Shell executives quit amid discord over green push' [online article], Financial Times, 8 December, <https://www.ft.com/content/053663f1-0320-4b83-be31fefbc49b0efc>, accessed 5 January 2021.

Rüttinger, L. and Vigya, S. (2016), Climate Change and Mining. A Foreign Policy Perspective. Berlin: Adelphi. <https://www.adelphi. de/en/publication/climate-change-and-mining $>$, accessed 4 December 2020

UN (United Nations) (2015), Paris Agreement, <https://unfccc. int/sites/default/files/english_paris_agreement.pdf $>$, accessed 4 December 2020

UNU WIDER (United Nations University World Institute for Development Economics Research) (2017), The Implications of Climate Change for the Extractive Industries. WIDER Research Brief 2017/4. Helsinki: UNU-WIDER. <https://www.wider.unu.edu/ sites/default/files/RB2017-4-The-implications-of-climate-changefor-extractive-industries.pdf>, accessed 4 December 2020. 
Appendix A:

\section{Sample companies}

\begin{tabular}{|c|c|c|c|}
\hline COMPANY & COUNTRY & COMPANY & COUNTRY \\
\hline Integrated oil and gas & & Copper & \\
\hline YPF SA & ARGENTINA & KGHM Polska Miedz SA & POLAND \\
\hline OMV AG & AUSTRIA & Antofagasta PLC & UNITED KINGDOM \\
\hline Petroleo Brasileiro SA Petrobras & BRAZIL & Kaz Minerals PLC & UNITED KINGDOM \\
\hline Cenovus Energy Inc & CANADA & & \\
\hline Husky Energy Inc & CANADA & General mining & \\
\hline Suncor Energy Inc & CANADA & BHP Group Ltd & AUSTRALIA \\
\hline Ecopetrol SA & COLOMBIA & South32 Ltd & AUSTRALIA \\
\hline Total SE & FRANCE & Teck Resources Ltd & CANADA \\
\hline MOL Magyar Olajes Gazipari Nyrt & HUNGARY & Imerys SA & FRANCE \\
\hline Oil and Natural Gas Corporation Ltd & INDIA & Anglo American plc & UNITED KINGDOM \\
\hline Eni SpA & ITALY & Glencore PLC & UNITED KINGDOM \\
\hline Petronas Dagangan Bhd & MALAYSIA & Rio Tinto PLC & UNITED KINGDOM \\
\hline Royal Dutch Shell PLC & NETHERLANDS & & \\
\hline Equinor ASA & NORWAY & Gold mining & \\
\hline Polskie Gornictwo Naftowe i Gaz. SA & POLAND & Barrick Gold Corp & CANADA \\
\hline Galp Energia SGPS SA & PORTUGAL & Zijin Mining Group Co Ltd & CHINA \\
\hline Gazprom Neft' PAO & RUSSIAN FEDER. & Polyus PAO & RUSSIAN FEDER. \\
\hline Gazprom PAO & RUSSIAN FEDER. & AngloGold Ashanti Ltd & SOUTH AFRICA \\
\hline NK Lukoil PAO & RUSSIAN FEDER. & & \\
\hline NK Rosneft' PAO & RUSSIAN FEDER. & Iron and steel & \\
\hline Novatek PAO & RUSSIAN FEDER. & Fortescue Metals Group Ltd & AUSTRALIA \\
\hline Repsol SA & SPAIN & Vale SA & BRAZIL \\
\hline PTT PCL & THAILAND & JSW Steel Ltd & INDIA \\
\hline \multirow[t]{2}{*}{ BP PLC } & UNITED KINGDOM & Steel Authority of India Ltd & INDIA \\
\hline & & Tata Steel Ltd & INDIA \\
\hline Oil: crude producers & & Vedanta Ltd & INDIA \\
\hline Santos Ltd & AUSTRALIA & ArcelorMittal SA & NETHERLANDS \\
\hline Woodside Petroleum Ltd & AUSTRALIA & Novolipetsk Steel PAO & RUSSIAN FEDER. \\
\hline Canadian Natural Resources Ltd & CANADA & Severstal' PAO & RUSSIAN FEDER. \\
\hline Crescent Point Energy Corp & CANADA & EVRAZ plc & UNITED KINGDOM \\
\hline CNOOC Ltd & HONG KONG & Ferrexpo PLC & UNITED KINGDOM \\
\hline \multirow[t]{2}{*}{ PTT Exploration and Production PCL } & THAILAND & & \\
\hline & & Platinum and precious metals & \\
\hline Aluminum & & Anglo American Platinum Ltd & SOUTH AFRICA \\
\hline \multirow[t]{2}{*}{ Norsk Hydro ASA } & NORWAY & Impala Platinum Holdings Ltd & SOUTH AFRICA \\
\hline & & Sibanye Stillwater Ltd & SOUTH AFRICA \\
\hline \multicolumn{4}{|l|}{ Coal } \\
\hline Banpu PCL & THAILAND & & \\
\hline
\end{tabular}




\title{
Appendix B1.
}

\section{Instrument for annual report analysis: Front end}

\author{
RESERVES AND RESOURCES REPORTING/STATEMENT \\ RRR1 Does the company provide a reserves/resources statement with relevant numerical information? \\ RRR2 Does the company report an assessment of climate change/environment-related risks and/or liabilities that are \\ pertinent to its projects, including, but not limited to, legislative requirements, assumptions and limitations?
}

\section{SCENARIO ANALYSIS}

SA1 Does the company provide scenario analysis which considers climate change risks?

SA2 For the companies that provide a scenario analysis as above, do they provide, within this, quantitative information about the climate change factors, assumptions and impacts of their operations?

\section{BUSINESS MODEL}

BM1 Does the company explicitly discuss its business model?

BM2 Does the company identify addressing climate change risk as an integral part of its business model?

BM3 Does the company consider any international initiative for climate change (eg the Paris Agreement) in the discussion of its business model?

\section{CLIMATE CHANGE-RELATED PERFORMANCE INDICATORS (PIS)}

KPI1 Does the company have climate change-related PIs?

KPI2 Does the company integrate financial and climate change-related information into its Pls?

KPI3 Does the company link executives' remuneration to climate change-related performance metrics?

TCFD Does the company follow the recommendations of the Task Force on Climate-related Financial Disclosures? 


\title{
Appendix B1.
}

\section{Instrument for annual report analysis: Back end}

\author{
ACCOUNTING POLICIES NOTE \\ AP1 Is climate change recognised as an important factor in the company's judgements and sources of estimations \\ uncertainty? - In financial instruments? \\ AP2 Is climate change recognised as an important factor in the company's judgements and sources of estimations \\ uncertainty? - In tangible and intangible assets? \\ AP3 Is climate change recognised as an important factor in the company's judgements and sources of estimations \\ uncertainty? - In exploration and evaluation assets? \\ AP4 Is climate change recognised as an important factor in the company's judgements and sources of estimations \\ uncertainty? - In impairment testing? \\ AP5 Is climate change recognised as an important factor in the company's judgements and sources of estimations \\ uncertainty? - In provisions and contingent liabilities? \\ IMPAIRMENT TESTING NOTE \\ IT1 Is climate change risk recognised to affect the company's future estimated cash flows and hence the recoverable \\ amount of its assets such as property, plant and equipment; mineral resources; evaluation and exploration \\ assets; financial instruments; intangible assets; and goodwill? \\ IT2 When a company recognises impairments, does it recognise climate risk factors affecting these?
}

\section{NON-CURRENT ASSETS NOTE}

NCA1 Are climate change-related risks considered when estimating the useful lives of the company's assets?

NCA2 Does the company capitalise expenses related to climate change?

NCA3 Does the company use financial instruments in order to settle future environmental obligations? (eg South Africa fund)

NCA4 Does the company recognise carbon allowances as intangible assets?

\section{PROVISIONS AND CONTINGENT LIABILITIES NOTE}

PCL1 Does the company consider climate change-related risks in the estimation of its provisions?

PCL2 Does the company identify climate change risk as important factor in its contingent liabilities?

\section{AUDIT REPORT}




\section{PI-CLIMATE-RISK-EI}

ACCA The Adelphi 1/11 John Adam Street London WC2N 6AU United Kingdom / +44 (0)20 70595000 / www.accaglobal.com 